\title{
VALIDATION OF BREAD WHEAT KASP MARKERS IN DURUM WHEAT LINES IN KAZAKHSTAN
}

\author{
Shynar Anuarbek ${ }^{1,2}$, Saule Abugalieva ${ }^{1,2}$, and Yerlan Turuspekov ${ }^{1,2, \#}$ \\ ${ }^{1}$ Al-Farabi Kazakh National University, 71 Av. al-Farabi, 050040, Almaty, KAZAKHSTAN \\ ${ }^{2}$ Institute of Plant Biology and Biotechnology, 45 Timiryazev Str., 050040, Almaty, KAZAKHSTAN \\ \# Corresponding author, yerlant@yahoo.com
}

Communicated by Isaak Rashal

\begin{abstract}
Development of efficient DNA markers plays an important role in modern breeding projects of many crops, including cultivated hexaploid bread wheat (BW) and tetraploid durum wheat (DW). Findings of genome-wide association studies on major polyploid crops, such as BW, may also help in molecular breeding studies in relative cultivated species with a similar genetic background, including DW. Therefore, the validation of identified quantitative trait loci or marker-trait associations is an important preliminary step in marker-assisted selection (MAS) oriented projects. In this study, thirty-two SNP (single nucleotide polymorphism) markers of six agronomic traits identified in BW, harvested in Kazakhstan, were converted to KASP (Kompetitive Allele-Specific PCR) assays. Generated 32 KASP assays were used in the analysis of 29 DW accessions from Kazakhstan. Firstly, the group of DW accessions was tested using replicated and randomised one-metre blocks in field conditions of southeast Kazakhstan and evaluated for main agronomic traits. The analysis showed that 14 KASP assays were polymorphic in the scoring of 29 DW accessions. The t-test suggested that the segregation in eight KASP assays was significantly associated with five agronomic traits. The study confirms robustness of KASP assays in MAS of DW breeding projects for the improvement of yield potential.
\end{abstract}

Key words: durum wheat, SNP, KASP assays, yield components.

DNA technologies that derived from genomic studies have offered a great promise for breeding projects based on marker-assisted selection (MAS) approach. There are five main considerations regarding the use of DNA markers in MAS: their reliability and reproducibility, the required quantity and quality of DNA, the technical procedure of marker assay; the polymorphism level, and costs (Collard and Mackill, 2008). Considering these requirements, KASP (KBioscience Kompetitive Allele-Specific PCR) was recently proposed as a very promising tool for the acceleration of crop breeding (Semagn et al., 2014), and widely used to validate the importance of SNPs (Neelam et al., 2013).

In the last decades, the identification of quantitative trait loci (QTL) using DNA markers (genotyping data), phenotyping data, and appropriate software were major breakthroughs in the characterisation of quantitative traits (Pozniak et al., 2007; Maccaferri et al., 2008; Sukumaran et al., 2018). As costs for high throughput genotyping are de- creasing, genome-wide association studies (GWAS) are becoming a powerful approach for the detection of QTLs associated with wheat agronomic traits. However, confirmation, validation of QTL, and fine (high resolution) mapping may be required. QTL validation is generally referred to as verifying that QTL is effective in different genetic backgrounds. Once tightly linked markers that reliably predict the phenotype of the trait have been identified, they can be used for MAS (Collard and Mackill, 2008).

Undoubtedly, the wealth of research data obtained in GWAS of hexaploid bread wheat (BW) can be efficiently used in many genetically closely related cultivated species, including in durum wheat (DW) (Periyannan et al., 2014; Qureshi et al., 2018). Therefore, the focus in this study was the validation of a group of SNP markers from the GWAS of BW (Turuspekov et al., 2017) in the analysis of DW accessions harvested in Kazakhstan. For this purpose, the group of identified SNP markers associated with agronomic 
traits in BW study was transformed into KASP arrays, which tested for the scoring of local DW accessions.

The DW panel consisted of 29 spring type cultivars and promising lines from Kazakhstan, Russian Federation, and Ukraine. The panel included 11 commercial cultivars that were officially registered through the State Seed Trials Commission of the Republic of Kazakhstan. The seeds were obtained from the Karabalyk Agricultural Experimental Stations (Kostanai region, Northern Kazakhstan) and Aktobe breeding station (Aktobe region, Western Kazakhstan).

The field trials were conducted at the Kazakh Research Institute of Agriculture and Plant Industry (KRIAPI, Almaty region, Kazakhstan, 4313'09" N, 76 41'17' E, altitude 740 $\mathrm{m}$ above sea level) in the growing season of 2018. The experimental design was a randomised complete block design with two replications under rainfed conditions. Experimental plots were $1 \mathrm{~m} \times 3 \mathrm{~m}$ with 20 rows spaced $0.2 \mathrm{~m}$ apart and with $5 \mathrm{~cm}$ between plants. The soil at the location is light chestnut (humus 2.0-2.5\%). The meteorological conditions of 2018 growing season are presented in Table 1. The cultivar Nauryz 2 was used as a check cultivar in the Almaty region. Phenological observations were carried out by the Zadoks scale (Zadoks, 1974). The analysis of yield components was carried out according to Dospekhov (Dospekhov, 1985). The following traits were recorded: plant height $(\mathrm{PH})$, peduncle length (PL), spike length (SL), number of fertile spikes per plant (NFS), number of kernels per spike (NKS), thousand kernels weight (TKW), and yield per plant (YPP).

DNA of 29 durum wheat cultivars was extracted from four day-seedlings according to the method of Dellaporta (Dellaporta et al., 1973). In addition to DW accessions, two DNA samples of BW cultivars of Kazakhstan were used as controls for each KASP-PCR. KASP markers were developed by using 32 identified SNPs for hexaploid wheat traits. Those SNP markers were previously revealed to be associated with flowering time (FT), seed maturation time (SMT), PL, TKW, NKS, NFS, and YPP, based on GWAS of the BW collection tested in Kazakhstan (Turuspekov et al., 2017). DNA sequences of identified SNP markers were used for the development of KASP assays by LGC Genomics Company (LGC Genomics, Beverly, MA, USA; Semagn

Table 1

AIR TEMPERATURE AND PRECIPITATION AT THE EXPERIMENTAL SITE IN 2018 (APRIL-AUGUST)

\begin{tabular}{c|c|c|c|c}
\hline & \multicolumn{4}{|c}{ Almaty region } \\
\hline Month & $\begin{array}{c}\mathrm{T} \text { min, } \\
{ }^{\circ} \mathrm{C}\end{array}$ & $\begin{array}{c}\mathrm{T} \max , \\
{ }^{\circ} \mathrm{C}\end{array}$ & $\begin{array}{c}\mathrm{T} \text { mean, } \\
{ }^{\circ} \mathrm{C}\end{array}$ & $\begin{array}{c}\text { Amount of precipitation, } \\
\mathrm{mm}\end{array}$ \\
\hline April & -0.5 & 14.6 & 12.5 & 81.6 \\
May & 6.0 & 22.7 & 16.3 & 124.9 \\
June & 11.6 & 28.1 & 22.3 & 29.3 \\
July & 17.5 & 31.5 & 25.2 & 32.3 \\
August & 13.9 & 30.3 & 24.4 & 43.5
\end{tabular}

$\mathrm{T}$ min - mean of minimal temperature, $\mathrm{T}$ max - mean of maximum temperature, $\mathrm{T}$ mean - average monthly temperature et al., 2013). Sequences of allele-specific and common primers are listed in Table 2 (only the markers that are significant in this study are given).

The polymerase chain reaction (PCR) was carried out according to the KASP assay manufacturer's recommendations. (LGC Genomics, Beverly, MA, USA). End-point fluorescence data were visualised with a plate reader Fluoroscan Ascent (Thermo Fisher Scientific, USA) and analysed using the genotype cluster analysis software KlusterCaller (LGC Group, www.lgcgroup.com/software). Statistical t-test was performed using RStudio (www.rstudio.com), and Pearson correlation index was calculated

T a ble 2

ALLELE-SPECIFIC AND COMMON PRIMERS FOR EIGHT SIGNIFICANT KASP MARKERS

\begin{tabular}{|c|c|c|c|c|}
\hline & Marker & Chr. & Primer & $\begin{array}{l}\text { Primer sequence ( } 5^{\prime}-3^{\prime} \text {, without tail } \\
\text { sequences) }\end{array}$ \\
\hline \multirow[t]{3}{*}{1} & BS00022431_51 & $4 \mathrm{~B}$ & A & GGAAGCAAAGGAGCTCGCT \\
\hline & & & $\mathrm{B}$ & GGAAGCAAAGGAGCTCGCC \\
\hline & & & $\mathrm{C}$ & ATCTTTTGCTGTGCCGTGGTGC \\
\hline \multirow[t]{3}{*}{2} & BS00066460_51 & $1 \mathrm{~A}$ & A & $\begin{array}{l}\text { CTACTTAGCCTTTGTTTGTTTC } \\
\text { GTA }\end{array}$ \\
\hline & & & B & $\begin{array}{l}\text { CTACTTAGCCTTTGTTTGTTTC } \\
\text { GTG }\end{array}$ \\
\hline & & & $\mathrm{C}$ & $\begin{array}{l}\text { CTATTGGCCATGGAAAGACTG } \\
\text { GTT }\end{array}$ \\
\hline \multirow[t]{3}{*}{3} & $\begin{array}{l}\text { GENE-2352_96 } \\
4\end{array}$ & $2 \mathrm{~A}$ & A & $\begin{array}{l}\text { TTGACCATGTATAGATACACG } \\
\text { CT }\end{array}$ \\
\hline & & & B & $\begin{array}{l}\text { TTGACCATGTATAGATACACG } \\
\text { CC }\end{array}$ \\
\hline & & & $\mathrm{C}$ & CATGCGTGTCACCTCAGTCT \\
\hline \multirow[t]{3}{*}{4} & BS00022689_51 & $5 \mathrm{~B}$ & A & $\begin{array}{l}\text { GCCTCAAAGACAAATTCTGAT } \\
\text { GGC }\end{array}$ \\
\hline & & & B & $\begin{array}{l}\text { GCCTCAAAGACAAATTCTGAT } \\
\text { GGT }\end{array}$ \\
\hline & & & $\mathrm{C}$ & $\begin{array}{l}\text { GAAGGAGATGTCATGCTCTTC } \\
\text { CGG }\end{array}$ \\
\hline \multirow[t]{3}{*}{5} & BS00037002_51 & $6 \mathrm{~A}$ & A & GGGTGTTTTTGTACCTGGCAC \\
\hline & & & $\mathrm{B}$ & GGGTGTTTTTGTACCTGGCAT \\
\hline & & & $\mathrm{C}$ & CATCTTCGGCATCAGCGCAT \\
\hline \multirow[t]{3}{*}{6} & $\begin{array}{l}\text { wsnp_Ex_c2470 } \\
033953160\end{array}$ & $1 \mathrm{~B}$ & A & AGCCTGCTCCCCAAGTATTTC \\
\hline & & & B & AGCCTGCTCCCCAAGTATTTT \\
\hline & & & $\mathrm{C}$ & TTCGGAACTGACAGTCGTGG \\
\hline \multirow[t]{3}{*}{7} & Kukri_c54_306 & $6 \mathrm{~B}$ & A & $\begin{array}{l}\text { CCAGCTCAGGGTTAGTCTGTA } \\
\mathrm{T}\end{array}$ \\
\hline & & & B & $\begin{array}{l}\text { CCAGCTCAGGGTTAGTCTGTA } \\
\text { C }\end{array}$ \\
\hline & & & $\mathrm{C}$ & GCGAGACGAAAAGAGCCGT \\
\hline \multirow[t]{3}{*}{8} & BS00067150_51 & $5 \mathrm{~A}$ & A & $\begin{array}{l}\text { CATGCACGTGGTACAGGGAAG } \\
\text { C }\end{array}$ \\
\hline & & & B & $\begin{array}{l}\text { CATGCACGTGGTACAGGGAAG } \\
\mathrm{T}\end{array}$ \\
\hline & & & $\mathrm{C}$ & $\begin{array}{l}\text { TAGAAAAGGGCCCCCGACTCT } \\
\text { CTGTTTCATA }\end{array}$ \\
\hline
\end{tabular}

Chr., chromosome; A, allele-specific primer 1; B, allele-specific primer 2; C, common primer 
using GraphPad Prism (v. 8.1.2; https://www.graphpad.com).

The Pearson correlation index suggested that YPP was negatively correlated with FT $(p<0.03)$, and positively with PH and TKW with low significance $(p<0.05)$, and PL, NFS, and NKS with high significance $(p<0.0001)$. Simultaneously, 32 SNP markers associated with agronomic traits in BW (Turuspekov et al., 2017) were initially converted to KASP assays and tested for $29 \mathrm{DW}$ accessions. It was found that 14 out of $32 \mathrm{KASP}$ assays were polymorphic for DW accessions. In general, 14 KASP assays could be separated into two groups according to the type of traits: i) plant development traits, and ii) yield-related components. The first group consisted of 11 assays that linked to QTL of FT and SMT in BW. The t-test suggested that five of these 11 assays were significantly associated with FT and SMT in DW. Particularly, it was shown that the polymorphism in KASP assays for GENE-2352_964 and BS00037002_51 were associated with FT. As it was mentioned above, FT plays an enormous role in plant adaptation and influences many agronomic traits. KASP assays for BS00066460_51, BS00067150_51, BS00022689_51 were associated not only with FT or SMT but also with yield components (NKS, TKW), indicating the pleiotropic effect of putative genetic factors. The remaining six KASP assays were not significantly related to studied traits in DW (Table 2, Fig. 1). The second group of DNA markers for yieldrelated components (NFS, NKS, TKW, YPP) consisted of three KASP polymorphic assays (Fig. 2). The t-test suggested that these three assays were significantly associated with yield components in studied DW accessions. Particularly, it was shown that KASP assay for wsnp_Ex_c24700_33953160 was associated with NKS, and assays for BS00022431_51 and Kukri_c54_306 with TKW, respectively.

Recently, Sukumaran with coauthors assessed a CIMMYT durum wheat panel grown under three different conditions (yield potential, drought and heat stresses) using DArTseq markers, and QTL hot-spots were found in durum wheat suggesting common marker-trait associations for stress indices and specific genomic locations for adaptation (Sukumaran et al., 2018). Interestingly, the chromosomal positions of three marker-trait associations (MTA) in this study were in the vicinity of the MTA identified in Sukumaran et al., 2018 under drought stress condition. Particularly, SNPs for FT (5A, $52.5 \mathrm{cM})$, NKS (1A, 78.6\%), and TKW (4B, 50.1 $\mathrm{cM})$ were in nearly the same positions for corresponding traits examined in Sukumaran et al., 2018, which partially verifies the robustness of the approach undertaken in this work.

Overall, the study confirms the high possibility in the exploitation of bread wheat DNA markers in durum wheat accessions, the robustness of GWAS in identification of important marker-trait associations in cereals, and the efficiency of KASP markers in the evaluation of genetic resources for important agronomic traits in DW and their high potential in marker-assisted selection of small cereals.
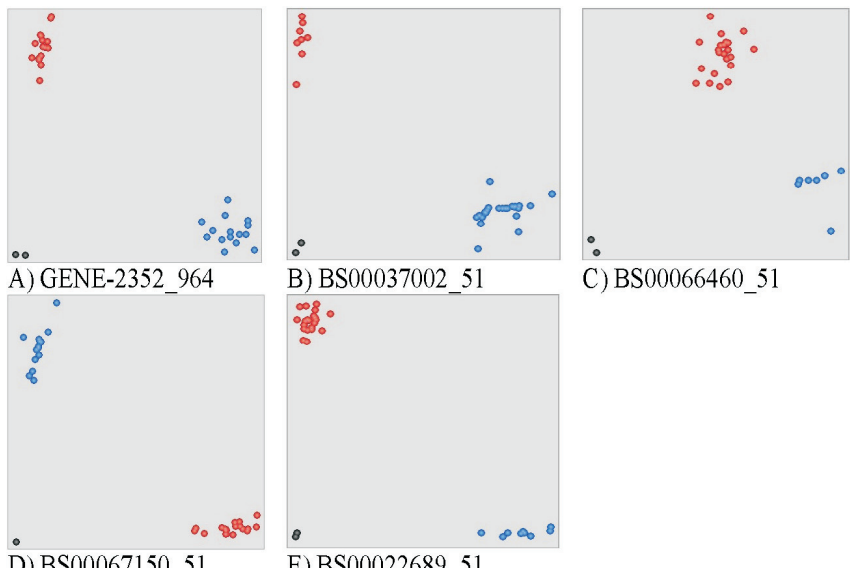

C) $\mathrm{BS} 0006646051$

D) $\mathrm{BS} 00067150 \quad 51$

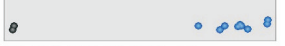

E) BS00022689 51

Fig. 1. Results of five KASP genotyping assays for flowering time used for screening 29 durum accessions. Red and blue dots represent homozygous genotypes with alternative alleles, and black circles are no-template water controls. A) GENE-2352_964; B) BS00037002_51; C) BS00066460_51; D) BS00067150_51; E) BS00022689_51.
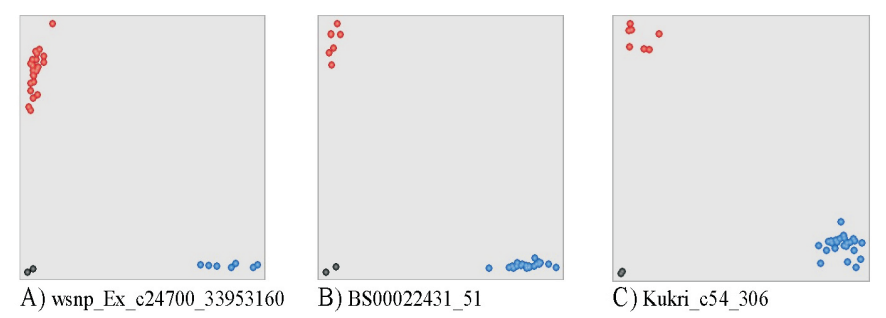

Fig. 2. Results of three KASP genotyping assays for yield components used for screening 29 durum wheat accessions. Red and blue dots represent homozygous genotypes with alternative alleles, and black circles are no-template water controls. A) wsnp_Ex_c24700_33953160; B) BS00022431_51; C) Kukri_c54_306.

\section{ACKNOWLEDGMENTS}

This work was conducted in the framework of the grant AP05131328 "QTL mapping of agronomic traits of durum wheat Triticum durum Desf. based on genome-wide association study" supported by the Ministry of Education and Science of Republic of Kazakhstan (2018-2020).

\section{REFERENCES}

Collard, B. C. Y, Mackill, D. J. (2008). Marker-assisted selection: an approach for precision plant breeding in the twenty-first century. Philos. Trans. R. Soc. Lond. B. Biol. Sci., 363 (1491), 557-572.

Dellaporta, S. L., Wood, J., Hicks, J. B. (1983). A plant DNA minipreparation: Version II. Plant Molecular Biology Reporter, 1 (4), 19-21.

Dospekhov, В. А. (1985). Field experiment methodology [Доспехов Б.А. Методика полевого опыта.] Kolos, Moscow. 351 pp. (in Russian).

Maccaferri, M., Sanguineti, M. C., Corneti, S., Ortega, J. L., Salem, M. B., Bort, J., Deambrogio, E. del Moral, L. F., Demontis, A., El-Ahmed, A., Maalouf, F., Machlab, H., Martos, V., Moragues, M., Motawaj, J., Nachit, M., Nserallah, N., Ouabbou, H., Royo, C., Slama, A., Tuberosa, R. (2008). Quantitative trait loci for grain yield and adaptation of durum wheat (Triticum durum Desf.) across a wide range of water availability. Genetics, 178, 489-511.

Periyannan, S. K., Qamar, Z. U., Bansal, U. K., Bariana, H. S. (2014). Development and validation of molecular markers linked with stem rust resistance gene Sr13 in durum wheat. Crop and Pasture Science, 65 (1), 74-79. 
Pozniak, C. J., Knox, R. E., Clarke, F. R., Clarke, J. M. (2007). Identification of QTL and association of a phytoene synthase gene with endosperm colour in durum wheat. Theor. Appl. Gen., 114, 525-537.

Qureshi, N., Bariana, H., Kumran, V. V., Muruga, S., Forrest, K. L., Hayden, M. J., Bansal, U. (2018). A new leaf rust resistance gene Lr79 mapped in chromosome 3BL from the durum wheat landrace Aus26582. Theor. Appl. Gen., 131 (5), 1091-1098.

Semagn, K., Babu, R., Hearne, S., Olsen, M. (2014). Single nucleotide polymorphism genotyping using Kompetitive Allele Specific PCR (KASP): overview of the technology and its application in crop improvement. Mol. Breeding, 33 (1), 1-14.

21 May 2019

Accepted in the final form 17 July 2019
Sukumaran, S., Reynolds, M. P., Sansaloni, C. (2018). Genome-wide association analyses identify QTL hotspots for yield and component traits in durum wheat grown under yield potential, drought, and heat stress environments. Front. Plant Sci., 9 (81).

Turuspekov, Y., Baibulatova, A., Yermekbayev, K., Tokhetova, L., Chudinov, V., Sereda, G., Ganal, M. W, Griffiths, S., Abugalieva, S. (2017). GWAS for plant growth stages and yield components in spring wheat (Triticum aestivum L.) harvested in three regions of Kazakhstan. BMC Plant Biology, 17 (190), 51-61.

Zadoks, J. C., Chang, T. T., Konzak, C. F. (1974). A decimal code for the growth stages of cereals. Weed Research, 14, 415-421.

\section{MAIZES KVIEŠU KASP MARĶIERU VALIDĀCIJA DURUM KVIEŠIEM KAZAHSTĀNĀ}

Uz marḳieriem balstītas izlases veikšanai selekcijas vajadzībām ir svarīgi zināt, vai vienai sugai izveidoti molekulārie marḳieri var tikt izmantoti citas radnieciskās sugas kvantitatīvo pazīmju identificēšanai. Šajā darbā tika validēti 32 KASP (Kompetitive Allele-Specific PCR) maizes kviešu markiieri uz 29 durum kviešu Kazahstānas paraugiem. Parādīts, ka šie markieri var tikt izmantoti maizes (mīksto) kviešu selekcijas programmās. 